УДК $94(477.52 / 54) \ll 190 / 192 »$

\title{
ШКОЛА ГІРНИЧИХ ДЕСЯТНИКІВ ІМЕНІ В. О. ВАГНЕРА ЯК ПРИКЛАД УСПІШНО РЕАЛІЗОВАНОЇ ОСВІТНЬОЇ ІНІЦІАТИВИ
}

\section{Шандра Ірина}

У статті досліджується історія створення та навчальний процес у школі гірничих десятників ім. В. О. Вагнера, яка була відкрита 1909 р. за ініціативою 3 'іздів гірничопромисловичв Півдня Росії (м. Харків), вуглепромисловиів Області Війська Донського та власне В. О. Вагнера (гірничий інженер, почесний член Ради 3'їздів гірничопромисловців Півдня Росії, начальник Південно-Східного гірничого управління Російської імперії). Цей навчальний заклад у статті розглядається як взірещь приватної ініціативи у гірничотехнічній освіті, адже державні діï у иій царині наприкінці XIX-на початку XX cm. відзначалися повільністю, організаційною й фінансовою обмеженістю. Приватна активність представницької корпорації та окремих підприємців показана в дослідженні як дія «груп інтересів», які, відповідно до корпоративістського підходу, є рушійними силами розвитку суспільства. Проведений аналіз роботи школи десятників ім. В. О. Вагнера засвідчив високий рівень підготовки спеціалістів, їхню затребуваність на виробництвах та популярність школи у робітничому середовищі. Тендениії розвитку, які відбувалися в професійній освіті на початку XX ст., можуть бути використані і в нинішніх умовах. Результативним буде підвищення кваліфікації персоналу на провідних промислових об'єктах сучасної Украӥни, безпосереднє ознайомлення робітників з новітніми технологіями, впровадженими у виробництво. Вивчення подібних прикладів організації навчальних закладів на підприємствах дозволить відродити українські традиџї бізнесу, мотивувати сучасних промисловців $і$ підприємиів опікуватися рівнем професіоналізму своїх працівників, постійно його підвищуючи. Звернення до історії школи гірничих десятників ім. В. О. Вагнера цінне своїм позитивним результатом: фахово складеними навчальними програмами, вдало організованим навчальним прочесом, поєднаним із практикою, та загальним належним рівнем підготовки випускників.

Ключові слова: школа десятників, В. О. Вагнер, гірничотехнічна освіта, 3 'їзди гірничопромисловиів Півдня Росії.

У сучасному інформаційному суспільстві заклади освіти часто не встигають за усіма технологічними інноваціями. Аби бути конкурентоспроможними на ринку праці, нормою сьогодення стає постійна участь працівників у різноманітних тренінгах і конференціях, проходження стажувань і курсів. Особливо ефективними такі методи підвищення кваліфікації стають, якщо вони безпосередньо наближені до практики та фінансуються зацікавленими підприємцями тоді зміст і форма підготовки максимально продумані. Одним із таких прикладів ефективної підготовки працівників для копалень Донбасу було заснування на початку XX ст. школи гірничих десятників ім. В. О. Вагнера. Загалом за рік слухачі школи опановували значний обсяг загальних та спеціальних дисциплін, знайомилися з новим обладнанням й технологіями видобутку на підприємствах Донбасу й Придніпров'я.

Проблема гірничотехнічної освіти на українських землях у другій половині XIX - на початку XX ст. порушується в кількох роботах автора [13; 14; 15]. Роз- 
витку професійної освіти на Катеринославщині в пореформений період присвячена стаття Л. Л. Прокопенко [2]. Окремого дослідження щодо історії створення та роботи школи гірничих десятників ім. В. О. Вагнера у сучасній українській історіографії не було проведено. Становитиме науковий і практичний інтерес дослідження цього навчального закладу, який плідно діяв на початку ХХ ст., з точки зору успішно реалізованої приватної освітньої ініціативи.

Школа десятників ім. В. О. Вагнера була організована при Макіївській рятувальній станції та знаходилася в структурі такого представницького об'єднання підприємців, як З'їзди гірничопромисловців Півдня Росії (м. Харків). Вивчення матеріалів роботи цієї представницької корпорації (звіти, протоколи, проекти, доповіді) дозволило простежити підготовчий та освітній процеси в школі, подати цінні фактичні й статистичні дані. Опрацювання статуту та навчальної програми школи десятників дозволило відтворити навчальний процес, його особливості та практичну спрямованість $[9 ; 10 ; 11]$.

Зважаючи на швидкі темпи економічного розвитку та крайню нестачу підготовлених майстрів рудничної і заводської праці, у 1889-1890 рр. проходив загальноімперський з’їзд діячів з технічної і професійної освіти. Щодо гірничозаводських навчальних закладів, учасники зборів висловилися за облаштування гірничозаводських шкіл при кожній більш-менш значній копальні чи заводі, а тим паче - при кожному гірничому окрузі $[3,83]$. Як підкреслювалося доповідачами, утримання такого навчального закладу на кошти власників підприємств мало забезпечити гідну підготовку фахівців, оскільки матеріальне забезпечення приватним капіталом було б значно кращим, ніж на урядові чи земські кошти; також викладання фахівцями-практиками, залученими із виробництв, було б результативнішим, а максимальна наближеність до виробництва дозволила б набути реальних практичних навичок і вмінь.

Ця ідея приватної ініціативи в гірничотехнічній освіті не була новою в Донбасі і успішно реалізовувалася на багатьох підприємствах. Питання технічної освіти було одним з пріоритетних і в роботі З’їддів гірничопромисловців Півдня Росії - представницької організації підприємців Донбасу й Придніпров'я. На засіданнях неодноразово наголошувалося, що розбудова спеціальних закладів освіти є невід'ємною умовою розвитку південної промисловості $[16,18]$. Власники промислових об'єктів були зацікавлені в тому, щоб мати кваліфікованих працівників, здатних оволодіти навичками роботи з обладнанням. Освіченість робітників об'єктивно сприяла підвищенню продуктивності та якості праці, зменшенню випадків травматизму на підприємствах i, відповідно, витрат на лікування й виплату грошової допомоги непрацездатним. Гірничопромисловці наголошували, що заклади освіти «покращують духовний рівень робітників, взагалі піднімають 
культуру робітництва» $[16,18] .3$ огляду на швидкий розвиток гірничої промисловості, збільшення штату гірничих техніків, штейгерів і десятників було нагальною потребою.

Під час роботи XXIV з'їзду гірничопромисловців Півдня Росії (1899р.) спеціальна комісія з гірничотехнічної освіти дійшла висновку, що «найбільш необхідними на сьогодні є елементарні річні школи для освіти десятників із числа робітників, не молодших 22 років, які прослужили на копальні не менше двох років і проявили себе 3 хорошого боку» $[4, \mathrm{C}-\mathrm{CI}]$. Активну участь у вивченні та розробці заходів із цього питання взяв і В. О. Вагнер; як керівник гірничої частини Області Війська Донського він висунув кілька цікавих пропозицій та рекомендацій. Відтоді розпочалася підготовча робота для відкриття школи гірничих десятників В. О. Вагнера.

Незважаючи на солідний статус ініціатора, урядове узгодження освітнього проекту зайняло десять років, перш ніж такий необхідний для промисловості навчальний заклад відкрив свої двері для слухачів. Тільки 23 серпня 1908 р. міністерство торгівлі й промисловості затвердило індивідуальний статут школи гірничих десятників імені В. О. Вагнера при Макіївській рятувальній станції.

Присвята цієї школи була не випадковою. Гірничий інженер, таємний радник Володимир Олександрович Вагнер був почесним членом Ради 3'їздів гірничопромисловців Півдня Росії, багаторічним головою з’їздів гірничопромисловців, начальником Південно-Східного гірничого управління. Уродженець Петербурзької губернії, Вагнер усе своє професійне життя пов'язав з промисловим Донбасом. Сучасники відзначали його невичерпну енергію, ясний розум й величезну працездатність. Він не обмежувався тільки промислово-виробничими питаннями, а й брав активну участь у благодійних проектах соціально-просвітницького спрямування. Як писав представник донських вуглепромисловців, міський голова Олександрівська-Грушевського Б. М. Файвишевич, «у приватному житті В. О. був чарівною людиною, люб'язним, привітним й відверто простим, жваво цікавився всіма явищами нашого громадського й політичного життя, вражаючи і дивуючи молодістю своєї душі» [12, 9212].

Ще 1899 р. вуглепромисловці Області Війська Донського ухвалили рішення створити фонд для заснування школи десятників ім. В. О. Вагнера. На XXXII з'їзді гірничопромисловців (1907р.) було виділено необхідні кошти на будівництво приміщення та утримання школи [12, 9210-9211]. На підставі постанови XXXIII з'їзду (1908р.) Рада 3’їздів побудувала в с. Макіївці (Область Війська Донського) приміщення школи, відкриття якої відбулося в 1909 р. Школа розташовувалася поблизу технічних будівель і навчального штреку першої в імперії центральної рятувальної станції - Макіївської. Ділянкою для навчально-до- 
слідних робіт була територія колишньої головної контори закритої шахти «Стара Капітальна» (ділянка розміром 60 на 45 сажень) Російсько-Донецького товариства кам'яновугільної й заводської промисловості.

Початок роботи школи було приурочено до 50-річчя службової діяльності Вагнера, тому подія відзначалася $з$ додатковим розмахом та пишністю. Школа знаходилася у підпорядкуванні навчального відділу міністерства торгівлі й промисловості, мала свою печатку із надписом «Школа горных десятников В. А. Вагнера» $[10,41]$.

До школи приймалися працівники, які мали гірничий підземний стаж не менше двох років, у тому числі не менше 3-х місяців - забійником. Крім теоретичних занять, обов'язковим були практичне вивчення всіх рудничних робіт, підземні зйомки, нанесення планів, а також рятувальні роботи [6, 76-77]. Учні проходили підготовку протягом року, перебуваючи на повному забезпеченні Ради 3’їздів гірничопромисловців Півдня Росії [6, 80].

Для зарахування до школи потрібно було витримати перевірочні іспити 3 читання, письма й арифметики. Обов'язковим був медичний огляд щодо придатності до рудничних робіт. Якщо охочих вступити до школи було більше затвердженої Радою З’їздів гірничопромисловців кількості місць, зарахування проводилося на конкурсній основі.

Навчальний курс школи був розрахований на один рік: початок занять 15 вересня, закінчення - 15 серпня. Перший цикл занять тривав з вересня по грудень, далі слухачі проводили кілька тижнів на копальнях Російсько-Донецького товариства, де вони знайомилися з ремонтом і будовою різних шахтних механізмів. На початку нового календарного року навчання відновлювалося і тривало до Пасхальних свят, після двотижневої перерви поновлювалося до 1 червня, потім - 1,5-місячна практика на рудниках Донбасу, після чого всі поверталися до школи для короткого повторення курсу, а з 9 по 14 серпня тривали випускні іспити [6, 77]. Упродовж першого семестру паралельно з вивченням гірничого мистецтва увага приділялася загальним предметам (арифметика, геометрія, фізика тощо). Другий семестр був орієнтований здебільшого на отримання практичних навичок: щочетверга учні відвідували найближчі копальні, курс гірничої справи закінчувався дводенною великою екскурсією всієї школи на Щербинівську шахту.

Перший 1909 / 1910 навчальний рік розпочався без запізнень: будівельні роботи були завершені до 1 вересня, протягом трьох тижнів проводилися вступні випробування, і вже з 26 вересня розпочалися заняття. На подальше облаштування школи 3'їздами гірничопромисловців було додатково виділено 8235 руб. Крім того, було прийнято рішення додатково надавати фінансову допомогу здібним учням школи $[5,11]$. 
Перший набір складався з 30 осіб, які мали відповідний практичний досвід $[5,18]$. Середній вік учнів становив 23-24 роки, більшість вступників були із селян, 10 слухачів мали свої родини [6, 73-76]. Оскільки слухачі школи були з бідних верств і не мали заощаджень, Радою 3'їздів було прийнято рішення одруженим гірникам на утримання їхніх родин виділити безвідсоткову позичку (69 руб. щомісячно), яку вони мали повернути після закінчення школи та виходу на роботу $[6,76]$.

Навчання було безкоштовним, так само безкоштовно учні отримували харчування й місце в гуртожитку. Підготовка фахівців передбачала вивчення таких курсів: Закон Божий, російська мова, арифметика й основи геометрії, фізика й механіка, креслення та гірнича майстерність $[10,42]$. Курс «Гірничої майстерності» був основним і складався з таких розділів: гірнича справа (побудова земної кори, корисні копалини й мінерали, геологічна будова Донбасу, розвідка родовищ), гірничі роботи (типи гірничих інструментів, вибухові речовини та правила користування ними), гірничі виробки (копальня, шурф, водовідлив і провітрювання, кріплення та їхні види), доставка в копальні (види та принципи доставки, механічні транспортери, рейкові шляхи), підйом (рудничні канати, підйомні машини, сигналізація, правила підйому й спуску вантажів і робітників, облаштування драбин), водовідведення (властивості рудничної води, насоси, трубопроводи), розробка родовищ (відкриті розробки, підземні роботи), провітрювання копалень (рудничне повітря, його небезпека й запобіжні заходи, вентилятори, анемометри й заміри повітря), освітлення в копальнях (лампи освітлення та їхні види), ненормальні явища в копальнях (вибухи газу й пилу, рудничні пожежі, затоплення), рятувальна справа (респіратори, правила здійснення рятувальних робіт), а також урядові розпорядження щодо безпеки ведення гірничих робіт, обов'язки десятників тощо. Окремо викладався курс «Обміри», який передбачав вивчення геодезичних і маркшейдерських приладів, різних видів обмірів, складання планів і вміння їх читати. У навчальній програмі окремо наголошувалося, що при викладанні загальних предметів варто наводити конкретні приклади, формувати вправи і завдання на теми з рудничної практики, а спеціальних дисциплін - «звертати особливу увагу на практичний бік явищ і понять» [11, 48]. I дійсно, упродовж усього навчального року учні опановували практичні дії рятувальної справи, теслярства й ковальства, необхідні у гірничих роботах.

Практичні роботи передбачалися за такими напрямами: навчання рятувальним діям; надання першої медичної допомоги у разі нещасних випадків; підземні обміри й обміри на поверхні; теслярські роботи: кріплення, відбійка, буріння й паління шнурів. Заняття проводилися у звичайних класах, майстерні або кабінеті гірничого мистецтва; для навчальних потреб слухачів була облаштована 
бібліотека. Навчальними засобами були підручники й посібники, а також моделі й знаряддя з гірничої справи, мінералогічна й петрографічна колекції, найпростіші геодезичні, маркшейдерські й фізичні прилади. Увесь процес навчання проходив на грунтовній науковій і практичній основах, слухачі курсу мали «коритися керівництву школи, дотримуватися у приміщеннях школи порядку й гречності» $[10,44]$.

Наприкінці навчального року у школі проходили іспити у присутності представників Ради 3'їздів гірничопромисловців, осіб з Гірничої інспекції і досвідчених гірничопромисловців. Перелік випускних випробувань складався 3 таких дисциплін: російська мова й арифметика (письмово); механіка, фізика й креслення; рятувальна справа й надання першої допомоги; Закон Божий і російська мова (усно); арифметика і геометрія (усно); гірниче мистецтво [6, 77]. На іспити 1909 / 1910 навчального року були запрошені гірничі інженери Радигін і Макаров, завідувач технічним відділом Ради 3'їздів гірничопромисловців П. В. Кулібін та проф. В. І. Бауман.

У складі школі діяли безкоштовні вечірні курси, метою яких, як зазначалося в статуті, було «надання робітникам будь-якого віку, не молодше 12 років, початкових пізнань, необхідних для свідомого ставлення до роботи» $[9,49]$. На курсах викладалися такі предмети: Закон Божий, російська мова, арифметика, фізика, хімія, природознавство, креслення, загальна гігієна, гірнича й гірничозаводська справа.

Безпосереднє управління школою десятників здійснював завідувач, який обирався Радою 3'їздів гірничопромисловців Півдня Росії і затверджувався міністерством торгівлі й промисловості. Першим завідувачем школи був гірничий інженер М. В. Шишкін (член орендного товариства Берестово-Кальміуського рудника). Викладачі школи входили до складу педагогічного комітету, який вирішував усі навчально-виховні питання. За особливі заслуги в облаштуванні закладів професійної освіти 3'їзди гірничопромисловців обирали попечителів школи. Першим пожиттєвим почесним попечителем школи гірничих десятників був В. О. Вагнер. Утримання школи здійснювалося на капітал, зібраний донськими вуглепромисловцями з нагоди 40-річної діяльності таємного радника В. О. Вагнера, а також асигнувань 3'їздів гірничопромисловців Півдня Росії, інших приватних осіб та установ.

Щороку випускалося близько 30 фахівців, які отримували звання гірничих десятників зі «свідоцтвом про успішне закінчення повного курсу школи гірничих десятників з належними підписами та 3 додаванням печатки школи» [10, 42]. Першого навчального року випустили 29 осіб, усі вони були працевлаштовані на гірничих підприємствах Донбасу й Придніпров'я із щомісячним жалу- 
ванням 45-60 руб. [6, 28, 79]. Значна частина випускників школи отримувала відповідальні посади завідувачів рудничними роботами $[7,20]$. Охочих навчатися з року в рік ставало все більше. У 1917 р. від робітників було подано вже 98 заявок, за конкурсом пройшли тільки 45 осіб [1, 72]. Популярності школі, окрім гарантованого працевлаштування, додавав і її спеціальний статус, що забезпечував військовозобов'язаним право на відстрочку $[8,210]$.

Школа гірничих десятників ім. В. О. Вагнера була яскравим прикладом вдало організованого й продуманого професійно-освітнього процесу. На початку $\mathrm{XX}$ ст. цей навчальний заклад посів чільне місце у формуванні постійних і свідомих кадрів гірників. Щорічно 3'їзди гірничопромисловців Півдня Росії заслуховували звіти щодо роботи школи десятників, вносили необхідні корегування, вдосконалюючи як теоретичну, так і практичну підготовку слухачів. Безпосередня наближеність навчання до виробництва, висока зацікавленість підприємців у кваліфікованих кадрах працівників мали свій результат: приватна освітня ініціатива - «Школа гірничих десятників ім. В. О. Вагнера» - була впроваджена на гідному соціально-просвітницькому рівні. Становитиме науковий інтерес подальше вивчення освітнього напряму в діяльності як представницьких організацій підприємців, так і окремих власників заводів і копалень.

\begin{abstract}
The article investigates the history of the creation and the educational process at the Wagner mining school, which was initiated by the Congress of Miners of Southern Russia (Kharkiv) in 1909, the miners of the Don Region Army, and Wagner himself (mining engineer, honorary member of the Council of mines of the South of Russia, Chief of the Southeast Mining Department Russian empire). This educational institution is considered in the article as a model of private initiative in mining education, since the state actions in this area in the late XIX-early XX centuries were marked by slowness, organizational and financial limitations. Private activity of a representative corporation and individual entrepreneurs is shown in the study as the action of «interest groups», which in accordance with the corporatist approach, are the driving forces of social development. An analysis of the work of the Wagner corporal corps of schools showed the high level of training of specialists, their demand for production facilities and the popularity of the school in the working environment. Development trends that occurred in vocational education in the early XX century can be used in the current environment. It will be effective to improve the skills of the personnel at the leading industrial sites of modern Ukraine, to directly acquaint workers with the latest technologies introduced into production. Studying such examples of organization of educational establishments at enterprises will allow revive the Ukrainian traditions of business, to motivate modern industrialists and entrepreneurs to take care of the level of professionalism of their workers, constantly increasing it. An appeal to the history of the Wagner school of Mines is valuable for its positive results: professionally drawn curricula, a well-organized training process combined with practice, and an overall proper level of graduate training.
\end{abstract}

Keywords: school of corporals, Vladimir Wagner, mining education, Mining congresses of Southern Russia. 


\section{ДЖЕРЕЛА ТА ЛІТЕРАТУРА}

1. Отчет Совета Съезда XLI съезду горнопромышленников юга России за 1915-1916 отчетный год. Харьков: Типография Б. Бенгис, 1916. 164 с.

2. Прокопенко Л. Л. Розвиток професійної освіти на Катеринославщині у другій половині XIX - на початку XX ст. Придніпров'я: історико-краєзнавчі дослідження. 2015. Вип. 13. С. 154-163.

3. Съезд русских деятелей по техническому и профессиональному образованию в России. Т. 1. Санкт-Петербург: «Владимирская» типо-литография, 1891. [разд. паг.].

4. Труды XXIV съезда горнопромышленников Юга России. Ч. 1. Харьков: Паровая типография и литография Зильберберг, 1900. [разд. паг.].

5. Труды XXXIV съезда горнопромышленников Юга России. Т. 1. Харьков: Типография Б. Бенгис, 1910. [разд. паг.].

6. Труды XXXV съезда горнопромышленников Юга России (23 ноября - 9 декабря 1910 г.). Т. 2. Харьков, 1910. [разд. паг.].

7. Труды XXXVIII съезда горнопромышленников Юга России. Т. 1. Харьков: Типография Б. Бенгис, 1914. [разд. паг.].

8. Труды XLI съезда горнопромышленников Юга России (24 ноября - 4 декабря 1916 г.). Т. 2. Харьков, 1917. [разд. паг.].

9. Устав вечерних курсов для рабочих при рудничной школе Русско-Донецкого Общества и при школе горных десятников имени тайного советника В. А. Вагнера в Макеевке, Области Войска Донского. Справочная книга для горнопромышиленников Юга России. Ч. 1. Харьков: Типография «Мирный труд», 1916. С. 49-51.

10. Устав школы горных десятников имени В. А. Вагнера. Справочная книга для горнопромышленников Юга России. Ч. 1. Харьков: Типография «Мирный труд», 1916. С. 41-44.

11. Учебные программы школы десятников имени В. А. Вагнера. Справочная книга для горнопромышленников Юга России. Ч. 1. Харьков: Типография «Мирный труд», 1916. С. 45-48.

12. Файвишевич Б. Владимир Александрович Вагнер (некролог). Горно-заводское дело. 1914. № 27. С. 9208-9213.

13. Шандра И. А. Деятельность представительных организаций предпринимателей в социально-культурной сфере (вторая половина XIX - начало XX вв.). Л. Н. Гумилев атындавы Еуразия ұлттық университетінің Хабаршы / Вестник Евразийского начионального университета имени Л. Н. Гумилева (Астана). 2015. № 3 (106). С. 424-431. 
14. Шандра I. О. З’їзди гірничопромисловців Півдня Росії: створення та діяльність (1874-1918 рр.): монографія. Луганськ: Вид-во ДЗ «ЛНУ імені Тараса Шевченка», $2011.300 \mathrm{c}$.

15. Шандра I. О. Культурно-освітня діяльність представницької організації гірничопромисловців півдня Росії в другій половині XIX - на початку XX століття. Вісник ЛНПУ імені Тараса Шевченка. Історичні науки. 2005. № 14. C. 232-237.

16. Экстренный съезд горнопромышленников Юга России, происходивший в городе Харькове 5-11 мая 1900 г. Харьков, 1900. [разд. паг.].

\section{References}

1. Otchet Soveta Syezda XLI syezdu gornopromyshlennikov yuga Rossii za 19151916 otchetnyy god (1916) [Report of the Council of the Congress of the XLI Congress of Mine-Industrialists in the South of Russia for the period 1915-1916 fiscal years]. Kharkov: Tipografiya B. Bengis.

2. Prokopenko, L. L. (2015). Rozvytok profesiinoi osvity na Katerynoslavshchyni u druhii polovyni XIX - na pochatku XX st. [Development of vocational education at Katerinoslavshchina in the second half XIX - early XX century]. Prydniprovia: istoryko-kraieznavchi doslidzhennia, 13, 154-163.

3. Syezd russkikh deyateley po tekhnicheskomu i professionalnomu obrazovaniyu v Rossii (1891) [Congress of Russian personalities on technical and vocational education in Russia]. T. 1. Sankt-Peterburg: «Vladimirskaya» tipo-litografiya.

4. Trudy XXIV syezda gornopromyshlennikov Yuga Rossii (1900) [Proceedings of the XXIV Congress of Miners of the South of Russia]. Ch. 1. Kharkov: Parovaya tipografiya i litografiya Zilberberg.

5. Trudy XXXIV syezda gornopromyshlennikov Yuga Rossii (1910) [Proceedings of the XXXIV Congress of Miners of the South of Russia]. T. 1. Kharkov: Tipografiya B. Bengis.

6. Trudy XXXV syezda gornopromyshlennikov Yuga Rossii (23 noyabria - 9 dekabria 1910 g.) (1910) [Proceedings of the XXXV Congress of Miners of the South of Russia (23 november - 9 desember 1910)]. T. 2. Kharkov.

7. Trudy XXXVIII syezda gornopromyshlennikov Yuga Rossii (1914) [Proceedings of the XXXVIII Congress of Miners of the South of Russia]. T. 1. Kharkov: Tipografiya $\mathrm{B}$. Bengis.

8. Trudy XLI syezda gornopromyshlennikov Yuga Rossii (24 noyabrla - 4 dekabria 1916 g.) (1917) [Proceedings of the XLI Congress of Miners of the South of Russia (24 november - 4 desember 1916)]. T. 2. Kharkov. 
9. Ustav vechernikh kursov dlia rabochikh pri rudnichnoy shkole Russko-Donetskogo Obshchestva i pri shkole gornykh desiatnikov imeni taynogo sovetnika V. A. Vagnera v Makeyevke, Oblasti Voyska Donskogo. Spravochnaya kniga dlia gornopromyshlennikov Yuga Rossii (1916) [A reference book for the mining industry of the South of Russia]. Ch. 1. Kharkov: Tipografiya «Mirnyy trud», 49-51.

10. Ustav shkoly gornykh desiatnikov imeni V. A. Vagnera. Spravochnaya kniga dlia gornopromyshlennikov Yuga Rossii (1916) [A reference book for the mining industry of the South of Russia]. Ch. 1. Kharkov: Tipografiya «Mirnyy trud», 41-44.

11. Uchebnyye programmy shkoly desiatnikov imeni V. A. Vagnera. Spravochnaya kniga dlia gornopromyshlennikov Yuga Rossii (1916) [A reference book for the mining industry of the South of Russia]. Ch. 1. Kharkov: Tipografiya «Mirnyy trud», 45-48.

12. Fayvishevich, B. (1914). Vladimir Aleksandrovich Vagner (nekrolog) [Vladimir Alexandrovich Wagner (obituary)]. Gorno-zavodskoye delo, 27, 9208-9213.

13. Shandra, I. A. (2015). Deyatelnost predstavitelnykh organizatsiy predprinimateley $\mathrm{v}$ sotsialno-kulturnoy sfere (vtoraya polovina XIX - nachalo XX vv.) [Activities of representative organizations of entrepreneurs in the socio-cultural sphere (second half of XIX - beginning of XX century)]. Vestnik Yevraziyskogo natsionalnogo universiteta imeni L. N. Gumileva (Astana), 3 (106), 424-431.

14. Shandra, I. O. (2011). Zizdy hirnychopromyslovtsiv Pivdnia Rosii: stvorennia ta diialnist (1874-1918 rr.): monohrafiia [Mining Congress of the South of Russia: Creation and Activity (1874-1918): monograph]. Luhansk: Vyd-vo DZ «LNU imeni Tarasa Shevchenka».

15. Shandra, I. O. (2005). Kulturno-osvitnia diialnist predstavnytskoi orhanizatsii hirnychopromyslovtsiv pivdnia Rosii v druhii polovyni XIX - na pochatku XX stolittia [Cultural and educational activities of South Russia's representative organization in the second half of the XIX - beginning XX century]. Visnyk LNPU imeni Tarasa Shevchenka. Istorychni nauky, 14, 232-237.

16. Ekstrennyy syezd gornopromyshlennikov Yuga Rossii, proiskhodivshiy v gorode Kharkove 5-11 maya $1900 \mathrm{~g}$. (1900) [An emergency congress of miners of the South of Russia, held in Kharkov from May 5-11, 1900]. Kharkov. 